\title{
Innovative projects for sustainable development of cities (case of Saint-Petersburg)
}

\author{
Svetlana Evseeva ${ }^{1,{ }^{*}}$, Olga Kalchenko $^{1}$ and Oksana Evseeva $^{1}$ \\ ${ }^{1}$ Peter the Great St.Petersburg Polytechnic University, Polytechnicheskaya, 29, St. Petersburg, \\ 195251, Russia
}

\begin{abstract}
It is paid a great attention to the problem of sustainable development in modern society. The development of the economy is impossible without the usage of innovative projects in all areas of life. The process of urbanization poses new challenges, so the implementation of innovative projects aimed at sustainable development of cities takes on special significance. The objectives of the current study are definition of the consistency of the United Nations Sustainable Development Goals and ways to achieve the goals by 2030 for Saint-Petersburg; investigation into the experience of implementation of innovative projects for sustainable development in St. Petersburg; identification the consistency of the United Nations Sustainable Development Goals and innovative projects in St. Petersburg. Research methods used in the research are deduction and induction, system analysis, synthesis, comparison and generalization, statistical analysis. The main results include investigation into the experience of St. Petersburg in innovative projects for sustainable development. They showed that the UN's SDGs are reflected in the strategy of economic and social development of St. Petersburg until 2030, but partly; a number of pilot innovative projects in the city aimed at sustainable urban development (United Nations Sustainable Development Goals): Ensure access to water and sanitation for all; Ensure access to affordable, reliable, sustainable and modern energy for all; Make cities inclusive, safe, resilient and sustainable; Ensure sustainable consumption and production patterns. The paper contributes toward the knowledge of sustainable development at the city's level by analysing the experience of innovative projects in St. Petersburg.
\end{abstract}

\section{Introduction}

In the past few decades, there has been a significant increase of interest in innovative projects oriented towards sustainable development. Sustainable development is a process of change that uses the resource, the direction of investment, the orientation of scientific and technological development and institutional changes that are coordinated with each other and strengthen existing and future opportunities to meet human needs and aspirations. In many respects it is a matter of providing a quality of life for people and the environment that is non-decreasing in time - from generation to generation [1].

\footnotetext{
*Corresponding author: evseeva_sa@spbstu.ru
} 
The theory of sustainable development has become widely used in the modern world [2]. Sustainable development in the global society is considered as correct, uniform and balanced development: a process of change in which the exploitation of natural resources, financial development, scientific and technological development, personal development and institutional changes are coordinated in order to strengthen the present and future potential for satisfying human needs. People, the environment, economic activity are the main parts of the theory of sustainable development [3].

Many fundamental and applied investigations of Russian and foreign scientists are devoted to the issues of sustainable development. Warnke P., Schirrmeister E., Leitner K.H. [4], Hirooka M. [5], David Pearce, Edward Barbier, and Anil Markandya [2] and others made a significant contribution to the consideration of the theoretical aspects of sustainable development and growth. Bettencourt L. M., Lobo J., Helbing D., Kühnert C., and West G. B. consider that urbanization worldwide presents an urgent challenge for sustainable development [6].

The main task of the innovation economy towards sustainable development is to consider innovations not only from the economic point of view, but also according to social and ecological dimensions [2]. For sustainable development, the role of technology has a great importance [7].

According to the theory of innovative management, there are many innovative models, such as: open innovation; user-centred innovations; innovations in the sale of products; "Economical" innovations; innovations, based on developments, etc. There are a number of concepts for the orientation of innovation activities towards sustainable development [4]. "Green", environmental and eco-innovations are mainly used in the scientific literature as synonyms, but the notion of innovations oriented to sustainable development expands the concept and includes the social aspect [8].

The scientists proposed the concepts and models of innovations oriented towards sustainable development: the concept of "sustainably-oriented innovation system", the model of open and sustainable innovations (OSI), etc. [9]

17 United Nations Sustainable Development Goals (UN SDGs, 2015) are a key part of a large system of objectives and indicators for both the developing world and developed countries within the framework of the Organization for Economic Cooperation and Development (OECD). The goals and objectives of sustainable development are complex, global in nature and universally applicable. At the same time, they make it possible to take into account differences in national realities, opportunities, levels of development and respect for national strategies and priorities. Part of the SDGs is universal in nature and is of current importance for some regions of Russia.

A number of UN conceptual documents have been adopted recently:

"The future we want" (2012) determines the prospects of mankind in the 21 st century on the basis of the concept of sustainable development, the basis of which should be the "green" economy;

"The 2030 Agenda for Sustainable Development" (2015);

The Paris Climate Agreement (2015), which sets the priorities for combating the climate threat in the world and in all countries until 2030-2050.

The documents reflect specific goals for countries and peoples, quantitative indicators and sets of measures that allow governments to plan actions to implement the solutions they have developed.

Representatives from Russia took a key part in The 2015 United Nations Climate Change Conference in Paris (COP21), where measures to ensure sustainable development were discussed. The need for innovation focused on sustainable development to overcome technological backwardness as a result of post-Soviet economic reforms and the transition to an effective market economy has been noted by many scientists [10]. According to the 2016 
Global R\&D Funding Forecast, Russia's share in total spending on research and development is $2.8 \%$ (mainly in the commercial aerospace and defence industry, defence), and gross expenditure on R\&D is $1.5 \%$ of GDP in 2016.

Sustainable development became a very important issue not only at a country level but also at a city level. Nijkamp and Perrels [11] made a comparative overview of twelve European cities (Amsterdam, Dublin, Torino etc.) from the point of sustainability, identified challenge and potential of energy and environmental policies, made policy analysis of the cities project. Johnson [12] argued that social and environmental problems related to city growth can be serious threats to the full realization of the socio-economic contribution that cities can make. Mieg and Töpfer [13] investigated into institutional and social innovation for sustainable urban development.

Sustainable development study group, led by professor Blowers [14] conducted a largescale research on planning for a sustainable environment. Nidumolu, Prahalad and Rangaswami [15] identified sustainability challenges, competences and opportunities and considered sustainability to be the key driver of innovation now.

There are also a number of scientific papers devoted to the sustainable development of Russia [3]. E. Kutsenko analyses the Russian experience of supporting experimental innovation regional clusters, offers indicators of their sustainability [16]. A. Ivolga analyses the current state in the sphere of sustainable development of rural areas in the regions of Russia [3]. T. Malysheva and other scientists analysed several Russian and Tatarstan innovative producers focused on sustainable development [17]. However, studies devoted to the sustainable development of cities are still few.

All of the above determines the relevance of the chosen research topic and emphasizes the need to investigate the experience of innovative projects for sustainable development at the city level.

The objectives of the current study:

- to define the consistency of the United Nations Sustainable Development Goals and ways to achieve the goals by 2030 for Saint-Petersburg;

- to investigate into the experience of implementation of innovative projects for sustainable development in St. Petersburg;

- to identify the consistency of the United Nations Sustainable Development Goals and innovative projects in St. Petersburg.

\section{Materials and methods}

In order to attract public attention to the issues of environmental development in the Russian Federation, preservation of biological diversity and ensuring environmental safety, the year 2017 was declared the year of ecology and the year of specially protected natural areas in connection with the centenary of the first state natural reserve in our country (Barguzinsky). The Barguzinsky Nature Reserve was established at the very end of 1916, but according to the new style, its centenary jubilee falls on January 2017.

The main orientation is the introduction of innovative components into production processes and large-scale re-equipment of enterprises, which allows them to significantly improve their profitability while minimizing anthropogenic impact on the environment.

To the preliminary results of 2017 year of ecology in Russia are:

1. In 2017, the implementation of major infrastructure environmental projects, costing about 500 billion rubles (this year's event for 105 billion rubles) was launched. Large industrial enterprises, such as Nornickel (closure of production, expansion of capacity for sulfur recovery), RT-Invest (preparation of construction of incineration plants) and many others have started implementing major innovative projects aimed at sustainable development. 
2. The reform of the waste management system, initiated earlier, should be extended to all regions of Russia in 2019. To date, many regions, many enterprises are implementing this system.

3. Introduction of separate collection and recycling of waste. In 2017, it was decided to ban the disposal of certain types of waste, useful components (prohibition of scrap metal disposal from 2018, non-ferrous metals, from 2019 - plastic, plastic packaging, other types of waste). At the end of 2017, an amendment to the law of 2014 on the introduction of a waste management system should be adopted, in which some principles for the introduction of sorting are specified.

4. In 2017, three priority projects were adopted: "Clean Country", "Wild Nature of Russia" and "Clean Volga River".

The main emphasis of the "Clean Country" project is the elimination of past environmental damage. In 2017, 25 projects were launched in 13 regions, 10 projects are planned to be implemented: liquidation of old landfills, old production capacities.

The main focus of the "Wildlife" project is ecological tourism. Pilot national parks are selected for aligning the system with investors.

The priority "Clean Volga River" project for the purification of the Volga for a total of more than 254 billion rubles of federal, regional budgets and investors' funds for more than 100 billion rubles. The project includes the construction of treatment facilities, the elimination of environmental damage along the coast and will reduce the pollution level of the Volga nine times before 2025.

All-Russian public organization "Green Patrol" published a report (Table 1) "Environmental rating" of Russian regions. It is the most comprehensive environmental report on a national scale, compiled since 2007 four times a year. This rating is based on information from regional media, summaries of the Ministry of Emergency Situations and The Federal Service for Hydrometeorology and Environmental Monitoring of Russia (Roshydromet), official reports of local authorities and nature users, information on the hotline and materials of their own field research.

Table 1. Top-10 of the "Environmental rating" [18].

\begin{tabular}{|c|c|}
\hline $\begin{array}{c}\text { Place in } \\
\text { rating }\end{array}$ & Region \\
\hline 1. & Tambov region \\
\hline 2. & Altai republic \\
\hline 3. & Altai region \\
\hline 4. & Saint-Petersburg \\
\hline 5. & Chuvash republic \\
\hline 6. & Ulyanovsk region \\
\hline 7. & Moscow \\
\hline 8. & Belgorod region \\
\hline 9. & Murmansk region \\
\hline 10. & Kursk region \\
\hline
\end{tabular}

The worst ecological situation is observed in the Sverdlovsk region, and then along the increasing in the Chelyabinsk, Moscow, Irkutsk and Bryansk regions, Sevastopol, Leningrad region, the Republic of Buryatia, the Orenburg region and the Jewish Autonomous Region.

The negative rating of a number of regions is largely due to natural disasters: unprecedented heat and smoke from forest fires in Siberia, serious air pollution by emissions of hydrogen sulfide in the east of Moscow.

St. Petersburg, for the first time of compiling the report, was included in the first five regions of the "Environmental Rating". 
Data for the research are collected on the basis of official sources in the public domain Rosstat, Petrostat, Administration of St. Petersburg, Socio-economic development strategy of St. Petersburg until 2030. The data were taken for 15 years from 2002 till 2017. It is important to note that the official final results of the year of ecology will be available only in 2018.

In our paper St. Petersburg (Russia) was chosen as an object.

The article is a qualitative study - an empirical study in which data are not presented in the form of numbers [19]. Research methods used: system analysis, synthesis, comparison and generalization, deduction and induction, statistical analysis.

\section{Results}

St. Petersburg is one of the most innovative cities, the second largest scientific and technical center of Russia after Moscow. The share of organizations implementing innovation in St. Petersburg is just under 20\% [20].

In 2017 St. Petersburg entered the top five most environmentally friendly regions of the country. Figure 1 shows that by the beginning of 2017, investments in environmental protection and commissioning of the city's capacities had grown by $20-40 \%$ per year.

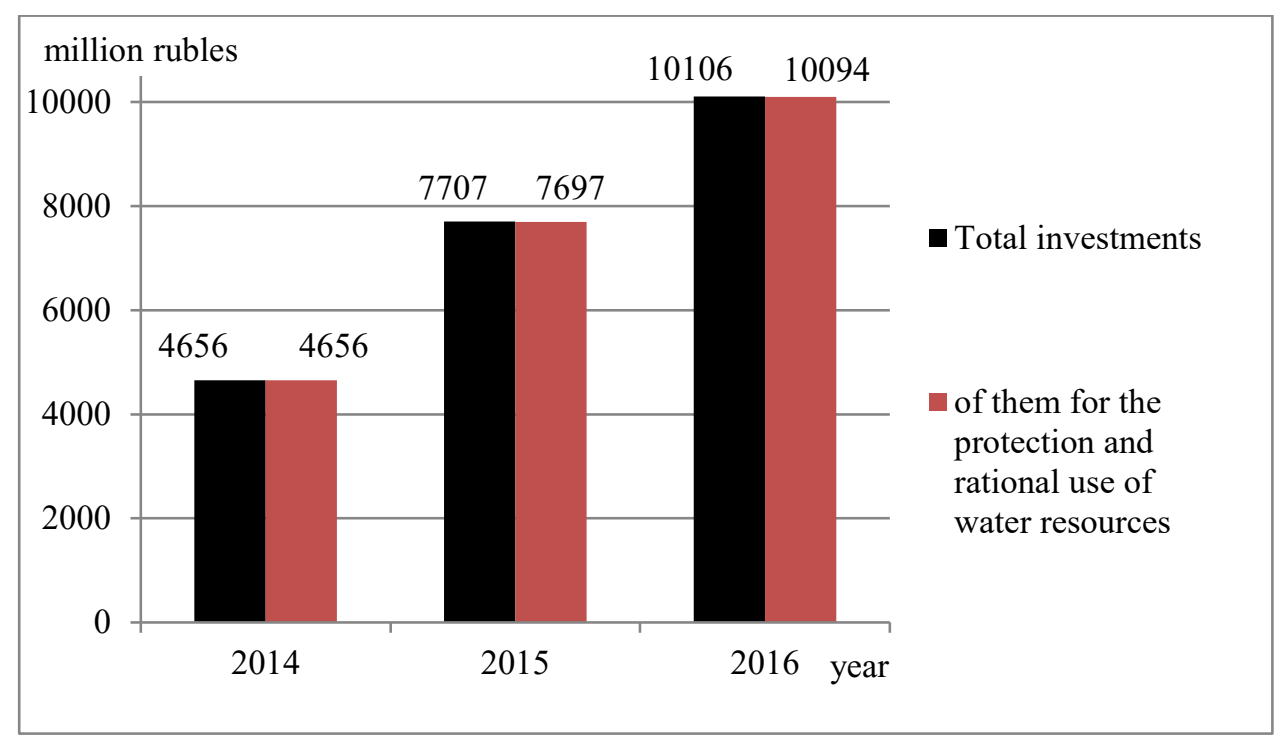

Fig. 1. Investments into environmental protection and commissioning of capacities [20].

The UN's SDGs formulated in the "The 2030 Agenda for Sustainable Development" is highlighted by the importance of the period 2016-2030.They reflect the ideology of sustainable development and the balance of social, economic and environmental priorities, and also contain concrete instruments of achievement. The UN adopted 17 goals and 169 tasks for their implementation. Taking into account the Russian realities and interests in each Goal, socio-ecological and economic priorities are singled out (Table 2) [21].

According to the current "Strategy of economic and social development of St. Petersburg until 2030", from the sustainable development point, the main long-term principles are to increase the efficiency of social, human [22] and natural capital. The document addresses innovative projects oriented to sustainable development, such as: waste sorting, waste disposal, clean energy. 
Table 2. United Nations Sustainable Development Goals (2016-2030 years) and ways to achieve the goals by 2030 (for Saint-Petersburg)* [1].

\begin{tabular}{|c|c|c|c|c|c|}
\hline \multirow[b]{2}{*}{$\begin{array}{l}\text { Goal } \\
\text { no. }\end{array}$} & \multirow[b]{2}{*}{$\begin{array}{l}\text { Sustainable Development } \\
\text { Goals }\end{array}$} & \multicolumn{3}{|c|}{$\begin{array}{l}\text { Priority (for } \\
\text { Russia) }\end{array}$} & \multirow[b]{2}{*}{$\begin{array}{c}\text { Ways to achieve the goals by } 2030 \text { (for } \\
\text { Saint-Petersburg) }\end{array}$} \\
\hline & & $\begin{array}{l}\frac{\pi}{0} \\
0 \\
0 \\
\infty\end{array}$ & 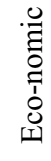 & $\begin{array}{l}\overline{0} \\
.00 \\
0 \\
0 \\
0 \\
0 \\
1\end{array}$ & \\
\hline 1. & $\begin{array}{l}\text { End poverty in all its } \\
\text { forms everywhere }\end{array}$ & $* *$ & $*$ & & $\begin{array}{l}\text { 1.1. Providing affordable housing for } \\
\text { citizens. }\end{array}$ \\
\hline 2. & $\begin{array}{l}\text { End hunger, achieve food } \\
\text { security and improved } \\
\text { nutrition and promote } \\
\text { sustainable agriculture }\end{array}$ & ** & & $*$ & $\begin{array}{l}\text { 2.1. Development of social support system } \\
\text { for citizents. }\end{array}$ \\
\hline 3. & $\begin{array}{l}\text { Ensure healthy lives and } \\
\text { promote well-being for } \\
\text { all at all ages }\end{array}$ & $* *$ & & & $\begin{array}{l}\text { 3.1. Demographic development; } \\
\text { 3.2. Development of the public health } \\
\text { system; } \\
\text { 3.3. Development of physical culture and } \\
\text { sports. }\end{array}$ \\
\hline 4. & $\begin{array}{l}\text { Ensure inclusive and } \\
\text { quality education for all } \\
\text { and promote lifelong } \\
\text { learning }\end{array}$ & $* *$ & & & $\begin{array}{l}\text { 4.1. Development of education, including } \\
\text { professional; } \\
\text { 4.2. Development of culture; } \\
\text { 4.3. Development of the system of } \\
\text { continuous education, training and } \\
\text { retraining of highly qualified staff for the } \\
\text { knowledge economy. }\end{array}$ \\
\hline 5. & $\begin{array}{l}\text { Achieve gender equality } \\
\text { and empower all women } \\
\text { and girls }\end{array}$ & $* *$ & & & $\begin{array}{l}\text { 5.1. Better integration of young people in } \\
\text { modern society. }\end{array}$ \\
\hline 6. & $\begin{array}{l}\text { Ensure access to water } \\
\text { and sanitation for all }\end{array}$ & $*$ & & $* *$ & 6.1. Improvement of city ecology. \\
\hline 7. & $\begin{array}{l}\text { Ensure access to } \\
\text { affordable, reliable, } \\
\text { sustainable and modern } \\
\text { energy for all }\end{array}$ & & $* *$ & $*$ & $\begin{array}{l}\text { 7.1. Development of energy and engineering } \\
\text { infrastructure. }\end{array}$ \\
\hline 8. & $\begin{array}{l}\text { Promote inclusive and } \\
\text { sustainable economic } \\
\text { growth, employment and } \\
\text { decent work for all }\end{array}$ & $*$ & & $* *$ & $\begin{array}{l}\text { 8.1. Economic development, establishment } \\
\text { of bases of } \\
\text { knowledge economy; } \\
\text { 8.2. Development of creative industries. }\end{array}$ \\
\hline 9. & $\begin{array}{lr}\text { Build } & \text { resilient } \\
\text { infrastructure, promote } \\
\text { sustainable } \\
\text { industrialization } \\
\text { foster innovation }\end{array}$ & & $* *$ & & $\begin{array}{l}\text { 9.1. Development of science and innovation } \\
\text { activity; } \\
\text { 9.2. Development of the construction } \\
\text { industry; } \\
\text { 9.3. Development of the real estate market } \\
\text { and support of development projects; } \\
\text { 9.4. Development of tourism; } \\
\text { 9.5. Improvement of urban territories; } \\
\text { 9.6. Development of the transport system. }\end{array}$ \\
\hline 10. & $\begin{array}{l}\text { Reduce inequality within } \\
\text { and among countries }\end{array}$ & $* *$ & & & $\begin{array}{l}10.1 \text { Development of interethnic and } \\
\text { interfaith relations. }\end{array}$ \\
\hline 11. & $\begin{array}{l}\text { Make cities inclusive, } \\
\text { safe, resilient and } \\
\text { sustainable }\end{array}$ & $* *$ & $*$ & & $\begin{array}{l}\text { 11.1. Development of St. Petersburg } \\
\text { agglomeration; } \\
\text { 11.2. Providing personal and public safety of } \\
\text { citizens. }\end{array}$ \\
\hline
\end{tabular}




\begin{tabular}{|c|c|c|c|c|c|}
\hline 12. & $\begin{array}{lr}\text { Ensure } & \text { sustainable } \\
\text { consumption } & \text { and } \\
\text { production patterns } & \\
\end{array}$ & $* *$ & $* *$ & $*$ & $\begin{array}{l}\text { 12.1. Development of trade and consumer } \\
\text { markets; } \\
\text { 12.2. Small business development. }\end{array}$ \\
\hline 13. & $\begin{array}{l}\text { Take urgent action to } \\
\text { combat climate change } \\
\text { and its impacts }\end{array}$ & & $*$ & ** & $\begin{array}{l}\text { 13.1 Innovation and technological } \\
\text { development of } \\
\text { industry. }\end{array}$ \\
\hline 14. & $\begin{array}{l}\text { Conserve and sustainably } \\
\text { use the oceans, seas and } \\
\text { marine resources }\end{array}$ & & $*$ & $* *$ & $\begin{array}{l}\text { 14.1. Providing activity connected with } \\
\text { Arctic zone development. }\end{array}$ \\
\hline 15. & $\begin{array}{l}\text { Sustainably manage } \\
\text { forests, combat } \\
\text { desertification, halt and } \\
\text { reverse land degradation, } \\
\text { halt biodiversity loss }\end{array}$ & & & ** & $\begin{array}{l}\text { 15.1. Territorial development of St. } \\
\text { Petersburg. }\end{array}$ \\
\hline 16. & $\begin{array}{l}\text { Promote just, peaceful } \\
\text { and inclusive societies }\end{array}$ & $* *$ & & & $\begin{array}{l}\text { 16.1. Improvement the quality of public } \\
\text { management; } \\
\text { 16.2. Development of conditions to ensure } \\
\text { public tolerance. }\end{array}$ \\
\hline 17. & $\begin{array}{lr}\text { Revitalize the global } \\
\text { partnership ror } \\
\text { sustainable development }\end{array}$ & $* *$ & $*$ & & $\begin{array}{l}\text { 17.1. Development of relations with social } \\
\text { organizations. }\end{array}$ \\
\hline
\end{tabular}

Note: ** is the primary priority for the Goal, * is the associated priority for the Goal.

* Compiled by the authors on the Strategy of economic and social development of St. Petersburg until $2030[21]$.

Pilot projects focused on sustainable development were launched in St. Petersburg in 2002.

Among innovative projects, oriented to sustainable development, we would like to highlight the following:

1. Since 2010, there is a system of regular collection of hazardous waste generated in everyday life, using mobile reception points - eco-cars of State Unitary Enterprise "Ecostroi". Mobile reception points represent a car equipped with special containers for collecting and transporting hazardous waste.

2. Since 2011, a separate collection of waste is being actively implemented by the project of the Ecology and environmental protection association "Razdelny Gathering". This movement originated in St. Petersburg and already has a wider coverage. To date, there are 1278 separate collection points in St. Petersburg, which is 1.5 times more than in the previous year.

3. Since 2012 in the city there are stationary collection points for hazardous waste stationary points, eco-terminals and terminals of eco-boxes of State Unitary Enterprise "Ecostroi" for collection of mercury lamps and batteries.

4. Advanced technologies in the field of energy efficiency are implemented by the CJSC "Eco-Energetika". "Eco-Energetika" is entered into the State register of innovations companies as a developer and owner of advanced domestic technologies in the field of power savings - the steam screw-type turbine SSM (Steam Screw-type Machine). Within the frames of a Complex program of measures for realization of innovations policy as well as in the purposes of execution of the Law "On power savings" that was approved by the State Duma of the Russian Federation as of 11.11.2009 CJSC "Eco-Energetika" realizes activities that are directed at increasing the volumes of realization of innovative products via implementation of advanced technologies in the field of power efficiency and resources savings.

The program of priority measures to ensure sustainable development of the economy and social stability in St. Petersburg in 2015 and for 2016 - 2017 was adopted with a view to reducing the negative impact on the economy and ensuring sustainable social and economic development of St. Petersburg. 
Among the first concrete results of the Program implementation in 2015: savings of more than 2 billion rubles in budget funds; reduction in the rate for the use of budgetary credits to $0.10 \%$ per annum; as well as savings of $14,913.7$ thousand $\mathrm{kWh}$ of electricity, 58.8 thousand Gcal thermal energy, 412.9 thousand cubic meters of gas supply, 609.1 thousand cubic meters of water supply and sanitation due to a reduction in the executive bodies of state power and recipients of the budget of St. Petersburg consumption of fuel and energy resources and water annually by $2 \%$. Also, in 2015, 37 normative legal acts were developed, 11 proposals for amending the federal legislation were prepared.

In 2016, as part of the Program, 68 chief administrators and recipients of the St. Petersburg budget announced the achievement of savings in fuel and water for 2016 in comparable conditions in 2015, including: for electricity 46546.2 thousand $\mathrm{kWh}$; for thermal energy 175.5 thousand Gcal; for gas supply 1323.5 thousand cubic meters; for water supply and sanitation 3062.8 thousand cubic meters.

Under the sign of 2017 year of ecology a wide range of projects aimed at protecting the environment and forming a comfortable environment for the life of the city environment [23] was implemented (Table 3), including more than 70 areas: work on improving the hazardous waste recycling system, programs for repair and reconstruction of heat networks, reconstruction of boiler houses, exhibitions, forums, actions, competitions.

Table 3. Preliminary results of 2017 year of ecology in St. Petersburg*.

\begin{tabular}{|l|l|}
\hline Protected areas & $\begin{array}{l}\text { List of territories for which is expected to hold integrated } \\
\text { environmental surveys, supplemented by nine new sections: Lisiy } \\
\text { nos, Tarkhovskiy cape, Levashovsky forest, Coast ledge Serovo, } \\
\text { Puhtolova gora, Babolovsky park, Sanctuary Yuntolovsky, Forest } \\
\text { park Gagarka, Sestrorezk dunes. }\end{array}$ \\
\hline Waste management & $\begin{array}{l}\text { St. Petersburg citizens handed over 80 tons of mercury-containing } \\
\text { waste and batteries, the total amount of collected hazardous waste } \\
\text { amounted to more than 250 tons during the year. }\end{array}$ \\
\hline $\begin{array}{l}\text { Elimination of } \\
\text { accumulated damage }\end{array}$ & $\begin{array}{l}\text { The landfill of toxic wastes Krasny Bor is brought to accident-free } \\
\text { state. }\end{array}$ \\
\hline $\begin{array}{l}\text { Environmental } \\
\text { education }\end{array}$ & $\begin{array}{l}\text { International forum Ecology of big city and Nevsky international } \\
\text { ecological congress. } \\
\text { Action "Hand over the batteries correctly!", eco-educational project } \\
\text { for children "Red wolf", the festival of nature reserves "The Neva's } \\
\text { guard", family ecofestival "Pavlovskaya squirrel", international } \\
\text { ecological art festival "Kronfest", a unique volunteer action to save } \\
\text { the amphibians on automobile roads of St. Petersburg, carried out in } \\
\text { order to prevent the death of migratory gray toads, sharp-nosed and } \\
\text { lake frogs under the wheels of cars. }\end{array}$ \\
\hline
\end{tabular}

*Compiled by the authors on the data of 2017 year of ecology in Russia [24].

More than 300 events with the participation of more than 703 thousand citizens were planned in St. Petersburg as part of 2017 year of ecology. More than 300000 citizens used the system of hazardous waste collection in St. Petersburg, including eco-cars, stationary points, eco-terminals and eco-boxes.

The most significant preliminary results of 2017 year of ecology in St. Petersburg are:

1. Closure of the Novoselki polygon, which was launched in 1972 and received up to 700,000 tons of waste annually. The reclamation plan is designed for seven years.

2. In 2017, the site "Interactive map of unauthorized dumps of Petersburg" appeared, on which 231 objects were marked.

3 . In 2017 , important steps were taken to move to a radically new waste management system, creating a territorial scheme was a good example of interaction between government bodies, business and public organizations.

Changes in lawmaking sphere, problems of separate collection of solid domestic wastes, 
processing and utilization of hazardous wastes, questions of formation of ecological culture of the population, results of urban environmental monitoring were discussed.

The accumulated experience in the implementation of environmental protection projects makes it possible to reduce the environmental load of industrial enterprises, to develop a cluster of water supply and sanitation.

\section{Discussion}

The importance of orientation to sustainable urban development is confirmed by the participation in the year of ecology, as well as by the growth of investments into environmental protection in St. Petersburg. Positive experience of successful implementation of environmental protection projects creates conditions for further development.

We found that St. Petersburg has developed a special official document - Strategy of economic and social development of St. Petersburg until 2030, aimed, among other things, to achieve the goals of sustainable development.

Not all The UN's SDGs are reflected in the strategy of economic and social development of St. Petersburg until 2030. Goals such as "End hunger, achieve food security and improved nutrition and promote sustainable agriculture", "Achieve gender equality and empower all women and girls", "Sustainably manage forests, combat desertification, halt and reverse land degradation, halt biodiversity loss" are not sufficiently reflected. Investigation of causes can be a separate topic for further research.

There are a number of pilot innovative projects in the city aimed at sustainable urban development. The first results of the implementation of innovative projects showed a positive effect in St. Petersburg.

This paper confirms Levy's hypothesis [9] that the most important responsibility and starting point for sustainable development lies in the management of technologies and innovations, with special emphasis on the importance of actions and guidelines, relative to the external environment (legal, economic, political, social, and environmental).

Effective development of innovative cities is necessary for the economic growth and development of countries. At the same time, social and environmental problems impede this process. And while they remain unresolved, the goal is not achieved [12]. Innovative solutions [25] can solve problems in context of economic, social and ecological dimensions. However, at present, the number of innovative projects aimed at sustainable development is still insufficient in St. Petersburg.

The analyzed innovative projects and activities aimed at sustainable development of St. Petersburg are consistent with the following United Nations Sustainable Development Goals:

No 6. Ensure access to water and sanitation for all (social and environmental priorities);

No 7. Ensure access to affordable, reliable, sustainable and modern energy for all (economic and environmental priorities);

No 11. Make cities inclusive, safe, resilient and sustainable (social and economic priorities);

No 12. Ensure sustainable consumption and production patterns (social, economic and environmental priorities).

Present research contributes toward the literature of sustainable development at the city's level by analyzing the experience of innovative projects in St. Petersburg. Our literature review search is not exhaustive. A much greater body of literature relating to sustainable development of cities and innovative projects implementation exists.

The article is limited to the Russian Federation and one city - St. Petersburg. St. Petersburg is a city of federal significance, a major innovation center of Russia. In other regions of Russia the situation can be very different. This restriction represents a prospect for future research. 


\section{Conclusions}

Innovative projects in cities are necessary for economic growth and development of countries. However, social and environmental problems hamper effective development. In this context innovative projects should be aimed at sustainable development of cities.

Our results develop the idea that sustainable development and innovative projects implementation are interdependent processes: sustainability is the key driver of innovation [15]; without innovative projects sustainable development of the city may be difficult [13].

According to the current study we defined the consistency of the United Nations Sustainable Development Goals and ways to achieve the goals by 2030 for Saint-Petersburg. Obtained results showed that all United Nations Sustainable Development Goals are covered in the strategy of economic and social development of St. Petersburg until 2030. However some of SDGs were reflected partly in the strategy of economic and social development of St. Petersburg until 2030. That also can serve as a recommendation for further elaboration of these goals for St. Petersburg. Innovative projects play an important role for sustainable development of St. Petersburg. Analyzed experience of innovative projects implementation for sustainable development in St. Petersburg reveals the shortage of them. The consistency of the United Nations Sustainable Development Goals and current innovative projects in St. Petersburg was defined.

The article promotes a broader discussion of the topic of implementing innovative projects aimed at sustainable development of cities.

Possible future directions of research may include the following:

- deeper investigation into city's innovative projects;

- comparative analysis of the impact of innovative projects on sustainable development of different cities and different regions of Russia;

- effectiveness evaluation influence of innovative projects to sustainable development of cities.

\section{References}

1. Assembly UN General "The Future we want (Resolution adopted by the General Assembly on 27 July 2012)" (2012)

2. D. Pearce, E. Barbier, A. Markandya, Sustainable Development: Economics and Environment in the Third World (Routledge, 2013)

3. A. Ivolga, Ekon. Poljoprivr. 61(2), 331 (2014)

4. P. Warnke, E. Schirrmeister, K.H. Leitner, In XXII ISPIM Conf., 12-15 (2011)

5. M. Hirooka, Innovation Dynamism and Economic Growth: A Nonlinear Perspective (Edward Elgar Publishing, 2006)

6. L.M. Bettencourt, J. Lobo, D. Helbing, C. Kühnert, G.B. West, Proc. of the nat. acad. of sc. 104(17), 7301-7306 (2007)

7. M.M. Andersen, L.G. Faria, R\&D Man Conf. 2015 (2015)

8. T. Schiederig, F. Tietze, C. Herstatt, R\&D Man 42(2), 180-192 (2012)

9. J.M. Levi, Proceed. of the 7th Intern. Conf. of ASECU, 425-437 (2011)

10. S.Y. Glazyev, G.G. Fetisov, Econ. and Soc. Chang.: Facts, Trends, Forecast 1, 18-28 (2013)

11. P. Nijkamp, A. Perrels, Sustainable cities in Europe (Routledge, 2014)

12. B. Johnson, Innov. 10(2-3), 146-155 (2008) 
13. H.A. Mieg, K. Töpfer, Institutional and social innovation for sustainable urban development (Routledge, 2013)

14. A. Blowers, Planning for a sustainable environment (Routledge, 2013)

15. R. Nidumolu, C.K. Prahalad, M.R. Rangaswami, Harv. bus. rev. 87(9), 56-64 (2009)

16. E. Kutsenko, Fors. - Rus. 9(1), 32-55 (2015)

17. T.V. Malysheva et al., Int. J. of Econ. and Fin. Iss. 6(1), 185-191 (2016)

18. Samye chistye I gryaznye regiony Rossii: itogi leta, http://www.natgeo.ru/nature/1126283- samye-chistye-i-gryaznye-regiony-rossii-itogi-leta/

19. K.F. Punch, Introduction to social research: Quantitative and qualitative approaches (Sage, 2013)

20. Upravlenie Federal'noj sluzhby gosudarstvennoj statistikipo g. Sankt-Peterburgu i Leningradskoj oblasti, http://petrostat.gks.ru/

21. Strategy of economic and social development of St. Petersburg until 2030, http://spbstrategy2030.ru

22. A.R. Bril, O.V. Kalinina, I.V. Ilin, Proc. of the 29th Int. Bus. Inf. Man. Ass. Conf. Man. through Vis. 2020, 2268-2277 (2017)

23. A.R. Bril, O.V. Kalinina, I.V. Ilin, MATEC Web of Conf. Int. Sc. Conf. SPbWOSCE2016 "SMART City", 106 (2017)

24. 2017 god ecologii v Rossii, http://ecoyear.ru/documents/

25. V.V. Glukhov, I.V. Ilin, A.I. Levina, Lect. Not. in Comp. Sci. 9247, 543-553 (2015) 